\title{
МИКРОЭКСТРАКЦИОННОЕ КОНЦЕНТРИРОВАНИЕ ХЛОРУКСУСНЫХ КИСЛОТ МЕТИЛ-ТРЕТ-БУТИЛОВЫМ ЭФИРОМ С ФЛОТАЦИОННЫМ ОТДЕЛЕНИЕМ \\ ЭКСТРАКТА
}

Сироткин Р.Г., Крылов В.А., Мосягин П.В., Елипашева Е.В.

Национальный исследовательский Нижегородский государственный университет

им. Н.И. Лобачевского, Нижний Новгород

roman_sirotkin94@mail.ru

DOI: 10.26902/ASFE-11_195

Хлоруксусные кислоты (моно-, ди- и трихлоруксусная) входят в число наиболее опасных загрязнений питьевой воды. Они являются побочными продуктами дезинфекции воды хлором или гипохлоритом натрия. Прямое ионохроматографическое определение этих веществ в воде осложнено их низким содержанием. Поэтому необходимо применение эффективного концентрирования.

Нами разработана методика жидкофазного микроэкстракционного концентрирования хлоруксусных кислот метил-трет-бутиловым эфиром. Эмульгирование экстрагента осуществляли ультразвуковым облучением. Впервые для деэмульсификации экстракта использован метод флотации. Эмульсию, полученную воздействием ультразвукового облучения, переносили в ампулу-экстрактор, позволяющую барботировать воздух из капилляров диаметром 0.2-0.3 мм, находящихся в донной части ампулы. Поток воздуха составлял 1.5 л/мин. Сбор экстракта осуществлялся в капилляре, припаянном в верхней части ампулы. При флотационном извлечении экстракта объем пробы был увеличен до 25 миллилитров. Кроме того, преимуществами разработанного метода деэмульсификации являются экспрессность и возможность автоматизации данной стадии анализа. Это выгодно отличает примененный метод от центрифужного. Коэффициенты концентрирования кислот составили 35-74, что в 7-10 раз больше, чем при использовании центрифугирования. Во время концентрирования происходило также отделение мешающих компонентов, благодаря чему не требовалась дополнительная стадия пробоподготовки.

Для устранения сложностей, связанных с анализом органического экстракта методом ионной хроматографии с кондуктометрическим детектированием, применена замена органической матрицы экстракта на водную путем испарения экстрагента из концентрата при комнатной температуре и растворения сухого остатка в элюенте. Достигнутые пределы обнаружения примесей составили $3 \cdot 10^{-4}-2 \cdot 10^{-3}$ мг/л. 